\title{
Front Matter: Volume 7392
}

, "Front Matter: Volume 7392," Proc. SPIE 7392, Metamaterials:

Fundamentals and Applications II, 739201 (23 September 2009); doi: 10.1117/12.847055

SPIE Event: SPIE NanoScience + Engineering, 2009, San Diego, California, United SPIE. States 


\section{PROCEEDINGS OF SPIE}

\section{Metamaterials: Fundamentals and Applications II}

Mikhail A. Noginov

Nikolay I. Zheludev

Allan D. Boardman

Nader Engheta

Editors

2-5 August 2009

San Diego, California, United States

Sponsored and Published by

SPIE

Volume 7392 
The papers included in this volume were part of the technical conference cited on the cover and title page. Papers were selected and subject to review by the editors and conference program committee. Some conference presentations may not be available for publication. The papers published in these proceedings reflect the work and thoughts of the authors and are published herein as submitted. The publisher is not responsible for the validity of the information or for any outcomes resulting from reliance thereon.

Please use the following format to cite material from this book:

Author(s), "Title of Paper," in Metamaterials: Fundamentals and Applications II, edited by Mikhail A. Noginov, Nikolay I. Zheludev, Allan D. Boardman, Nader Engheta, Proceedings of SPIE Vol. 7392 (SPIE, Bellingham, WA, 2009) Article CID Number.

ISSN 0277-786X

ISBN 9780819476821

Published by

SPIE

P.O. Box 10, Bellingham, Washington 98227-0010 USA

Telephone +1 3606763290 (Pacific Time) · Fax +1 3606471445

SPIE.org

Copyright (@ 2009, Society of Photo-Optical Instrumentation Engineers

Copying of material in this book for internal or personal use, or for the internal or personal use of specific clients, beyond the fair use provisions granted by the U.S. Copyright Law is authorized by SPIE subject to payment of copying fees. The Transactional Reporting Service base fee for this volume is $\$ 18.00$ per article (or portion thereof), which should be paid directly to the Copyright Clearance Center (CCC), 222 Rosewood Drive, Danvers, MA 01923. Payment may also be made electronically through CCC Online at copyright.com. Other copying for republication, resale, advertising or promotion, or any form of systematic or multiple reproduction of any material in this book is prohibited except with permission in writing from the publisher. The CCC fee code is 0277-786X/09/\$18.00.

Printed in the United States of America.

Publication of record for individual papers is online in the SPIE Digital Library.

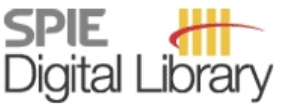

SPIEDigitalLibrary.org

Paper Numbering: Proceedings of SPIE follow an e-First publication model, with papers published first online and then in print and on CD-ROM. Papers are published as they are submitted and meet publication criteria. A unique, consistent, permanent citation identifier (CID) number is assigned to each article at the time of the first publication. Utilization of CIDs allows articles to be fully citable as soon they are published online, and connects the same identifier to all online, print, and electronic versions of the publication. SPIE uses a six-digit CID article numbering system in which:

- The first four digits correspond to the SPIE volume number.

- The last two digits indicate publication order within the volume using a Base 36 numbering system employing both numerals and letters. These two-number sets start with 00, 01, 02, 03, 04 , 05, 06, 07, 08, 09, OA, OB ... 0Z, followed by 10-1Z, 20-2Z, etc.

The CID number appears on each page of the manuscript. The complete citation is used on the first page, and an abbreviated version on subsequent pages. Numbers in the index correspond to the last two digits of the six-digit CID number. 


\section{Contents}

vii Conference Committee

ix Sub-nanometer resolution for the inspection of reflective surfaces using white light (Plenary Paper) [7405-37]

W. Jüptner, T. Bothe, Bremer Institut für angewandte Strahltechnik (Germany)

\section{NOVEL CONCEPTS AND PHENOMENA}

739204 Metamaterial resonators on curved surfaces [7392-03]

D. B. Burckel, P. Davids, I. Brener, G. A. Ten Eyck, A. R. Ellis, J. R. Wendt, B. S. Passmore,

E. A. Shaner, M. B. Sinclair, Sandia National Labs. (United States)

739205 Chaos in hyperspace: ray dynamics in media with hyperbolic dispersion (Invited Paper) [7392-04]

E. E. Narimanov, Purdue Univ. (United States)

\section{CHIRAL METAMATERIALS}

739208 Spectral signatures of chirality [7392-07]

J. G. Pedersen, N. A. Mortensen, Technical Univ. of Denmark (Denmark)

\section{ADVANCED APPLICATIONS}

7392 OB Plasmonic nanostructures for photo-catalytic reactors (Invited Paper) [7392-10]

K. P. Chiu, N. L. Wu, C. S. Wu, Y. H. Fu, C. H. Chu, H. Y. Chung, F. H. Chen, L. D. Lin, L. H. Huang, C. D. Shue, National Taiwan Univ. (Taiwan); D. P. Tsai, National Taiwan Univ. (Taiwan), Research Ctr. for Applied Sciences (Taiwan), and National Applied Research Labs. (Taiwan)

\section{THz AND MICROWAVE METAMATERIALS}

7392 OE Self-supported all-metal THz metamaterials (Invited Paper) [7392-13]

H. O. Moser, L. K. Jian, National Univ. of Singapore (Singapore); H. S. Chen, Massachusetts Institute of Technology (United States) and Zhejiang Univ. (China); M. Bahou,

S. M. P. Kalaiselvi, S. Virasawmy, S. M. Maniam, National Univ. of Singapore (Singapore); X. X. Cheng, Zhejiang Univ. (China); S. P. Heussler, S. bin Mahmood, National Univ. of Singapore (Singapore); B.-I. Wu, Massachusetts Institute of Technology (United States)

$73920 \mathrm{G}$ Terahertz near-field imaging of electric and magnetic resonances in metamaterials (Invited Paper) [7392-15]

M. Walther, A. Bitzer, Univ. of Freiburg (Germany) 
$7392 \mathrm{OH} \quad$ All-dielectric metamaterial: a ferroelectric-based scheme in the microwave range [7392-16]

T. Lepetit, Univ. Paris-Sud (France) and Thales Research \& Technology (France);

E. Akmansoy, Univ. Paris-Sud (France); J.-P. Ganne, Thales Research \& Technology (France)

\section{METAMATERIALS THEORY}

7392 OK On the homogenization of piezoelectric metamaterials via the strong-property-fluctuation theory: a numerical study (Invited Paper) [7392-18]

A. J. Duncan, Univ. of Edinburgh (United Kingdom); T. G. Mackay, Univ. of Edinburgh (United Kingdom) and The Pennsylvania State Univ. (United States); A. Lakhtakia, The Pennsylvania State Univ. (United States)

7392 OL Metamaterial homogenization: extraction of effective constitutive parameters [7392-19] C. Fietz, G. Shvets, The Univ. of Texas at Austin (United States)

7392 OM Molecular states in double quantum wells: nanochemistry for metatmaterials with new optical properties [7392-20]

R. M. Gutierrez, A. Castañeda, Univ. Antonio Nariño (Colombia)

$73920 Q$ Energy, momentum, and force in classical electrodynamics: application to negative-index media [7392-24]

M. Mansuripur, College of Optical Sciences, The Univ. of Arizona (United States);

A. R. Zakharian, Corning Inc. (United States)

\section{MODELING AND COMPUTATION}

7392 OS Ulam's method to estimate invariant measures and Lyapunov exponents for one-dimensional discretely randomized photonic structures [7392-26]

G. J. Kissel, Univ. of Southern Indiana (United States)

\section{FABRICATION AND SYNTHESIS}

7392 OY Direct laser writing of photonic nanostructures (Invited Paper) [7392-32]

I. Sakellari, A. Gaidukeviciute, A. Giakoumaki, D. Gray, C. Fotakis, M. Vamvakaki, M. Farsari, IESL-FORTH (Greece); C. Reinhardt, A. Ovsianikov, B. N. Chichkov, Laser Zentrum Hannover e.V. (Germany)

739210 Orientational order in systems of nanorods: side-by-side and end-to end controlled assembly using lyotropic chromonic materials (Invited Paper) [7392-34]

H.-S. Park, O. D. Lavrentovich, Kent State Univ. (United States)

\section{ACTIVE METAMATERIALS}

739214 Nonlinear guided waves in tuneable, gyrotropic, metamaterial complex structures (Invited Paper) [7392-38]

A. D. Boardman, P. Egan, R. C. Mitchell-Thomas, Y. G. Rapoport, Univ. of Salford (United Kingdom) 
739217 Nonlinear and tunable metamaterials (Invited Paper) [7392-41]

Y. S. Kivshar, The Australian National Univ. (Australia)

IMAGING WITH METAMATERIALS

739219 Magnified color imaging through plasmonic nanolens (Invited Paper) [7392-43]

S. Kawata, Osaka Univ. (Japan) and RIKEN (Japan); P. Verma, Osaka Univ. (Japan)

7392 1A Hypergratings: far-field subwavelength focusing in planar metamaterials (Invited Paper) [7392-44]

V. A. Podolskiy, S. Thongrattanasiri, Oregon State Univ. (United States)

7392 1D Near-field pattern synthesis at optical frequencies (Invited Paper) [7392-48]

L. Vegni, F. Bilotti, Univ. degli Studi di Roma Tre (Italy)

$73921 \mathrm{E} \quad$ A study of the image quality in a lossy NFSL [7392-49]

K. Lee, K. Kim, Yonsei Univ. (Korea, Republic of)

SPLIT RING RESONATORS

$73921 \mathrm{H} \quad$ Plasmonic couplings in split-ring resonators by electric excitation [7392-52]

C.-Y. Chen, T.-J. Yen, National Tsing Hua Univ. (Taiwan)

MAGNETIC PHENOMENA

$739211 \quad$ Optical magnetism in metal nanoforests (Invited Paper) [7392-53]

J. Cook, K. Tsakmakidis, O. Hess, Univ. of Surrey (United Kingdom)

\section{NEGATIVE INDEX MATERIALS}

$73921 \mathrm{M} \quad$ What is negative refraction? (Invited Paper) [7392-57]

M. W. McCall, P. Kinsler, A. Favaro, Imperial College London (United Kingdom); D. Censor, Ben-Gurion Univ. of the Negev (Israel)

7392 IN Novel homogeneous negative refractive index materials (Invited Paper) [7392-58]

A.-G. Kussow, A. Akyurtlu, Univ. of Massachusetts Lowell (United States)

$739210 \quad$ Negative refraction in split-ring-resonator stack at normal incidence [7392-59]

B. Kanté, R. Ghasemi, A. de Lustrac, J. Lourtioz, Institut d'Électronique Fondamentale, CNRS, Univ. Paris-Sud (France)

$73921 \mathrm{P} \quad$ Surface polaritons at a negative index material grating [7392-60]

M. Cuevas, R. A. Depine, Univ. de Buenos Aires (Argentina)

$73921 Q \quad$ Perturbation of multilayered structures of positive and negative index materials [7392-61]

R. Aylo, P. P. Banerjee, G. Nehmetallah, Univ. of Dayton (United States) 
POSTER SESSION

7392 is Coherent control of metamaterials [7392-63]

S. Chakrabarti, S. A. Ramakrishna, H. Wanare, Indian Institute of Technology, Kanpur (India)

Author Index 


\title{
Conference Committee
}

\author{
Symposium Chairs
}

David L. Andrews, University of East Anglia Norwich (United Kingdom) James G. Grote, Air Force Research Laboratory (United States)

Conference Chairs

Mikhail A. Noginov, Norfolk State University (United States)

Nikolay I. Zheludev, University of Southampton (United Kingdom)

Allan D. Boardman, University of Salford (United Kingdom)

Nader Engheta, University of Pennsylvania (United States)

Program Committee

David L. Andrews, University of East Anglia Norwich (United Kingdom)

Larry R. Dalton, University of Washington (United States)

Graeme Dewar, University of North Dakota (United States)

Ildar R. Gabitov, The University of Arizona (United States)

Francisco Javier Garcia de Abajo, Consejo Superior de

Investigaciones Científicas (Spain)

Satoshi Kawata, Osaka University (Japan)

Jacob B. Khurgin, The Johns Hopkins University (United States)

Yuri S. Kivshar, The Australian National University (Australia)

Joachim R. Krenn, Karl-Franzens-Universität Graz (Austria)

Akhlesh Lakhtakia, The Pennsylvania State University (United States)

Ulf Leonhardt, University of St. Andrews (United Kingdom)

Martin W. McCall, Imperial College London (United Kingdom)

Graeme Milton, The University of Utah (United States)

Herbert O. Moser, National Univ. of Singapore (Singapore)

Martin Moskovits, University of California, Santa Barbara (United States)

Evgenii E. Narimanov, Purdue University (United States)

Lixin Ran, Zhejiang University (China)

Andrey K. Sarychev, Institute of Theoretical and Applied

Electromagnetics (Russian Federation)

Vladimir M. Shalaev, Purdue University (United States)

Gennady Shvets, The University of Texas at Austin (United States)

Mark I. Stockman, Georgia State University (United States)

Sergei Tretyakov, Helsinki University of Technology (Finland)

Din Ping Tsai, National Taiwan University (Taiwan)

Lucio Vegni, Università degli Studi di Roma Tre (Italy) 
Session Chairs

Novel Concepts and Phenomena

Nader Engheta, University of Pennsylvania (United States)

Chiral Metamaterials

Allan D. Boardman, University of Salford (United Kingdom)

Advanced Applications

Mikhail A. Noginov, Norfolk State University (United States)

$\mathrm{THz}$ and Microwave Metamaterials

Steven M. Anlage, University of Maryland, College Park (United States)

Modeling and Computation

Satoshi Kawata, Osaka University (Japan)

Optical Transformations and Cloaking

Andrey K. Sarychev, Institute for Theoretical and Applied

Electromagnetics (Russian Federation)

Mark I. Stockman, Georgia State University (United States)

Fabrication and Synthesis

Nikolay I. Zheludev, University of Southampton (United Kingdom)

Active Metamaterials

Martin W. McCall, Imperial College London (United Kingdom)

Split Ring Resonators

Martin Moskovits, University of California, Santa Barbara (United States)

Magnetic Phenomena

Natalia M. Litchinitser, University at Buffalo (United States)

Negative Index Materials

Vladimir M. Shalaev, Purdue University (United States) 